\title{
Małgorzata Bajgier-Kowalska
}

Krakowska Akademia

im. A.F. Modrzewskiego

\section{Rola przedsiębiorczości lokalnej w dywersyfikacji produktu turystycznego Walencji (Hiszpania)}

\author{
The role of local entrepreneurship in the diversification of Valencia's tourism \\ product (Spain)
}

\begin{abstract}
Streszczenie
Jedną z najszybciej rozwijających się form ruchu turystycznego jest turystyka miejska, obejmująca zwłaszcza duże miasta o wielowiekowej tradycji. Globalne przekształcenia na międzynarodowym rynku turystycznym wpływają na znaczne zmiany ich działalności i prowadzenia wydajnych procesów restrukturyzacyjnych, niezbędnych do dostosowania się do nowych trendów w turystyce i oferowania turystom różnych form spędzania wolnego czasu. Celem niniejszego artykułu jest przedstawienie roli przedsiębiorczości lokalnej, zarówno władz samorządowych, jak i mieszkańców, w rozwoju różnych form turystyki miejskiej oraz szeregu rozwiązań instytucjonalnych zmierzających do zwiększenia ruchu turystycznego i podniesienia konkurencyjności Walencji, miasta położonego na hiszpańskim wybrzeżu Morza Śródziemnego.
\end{abstract}

\begin{abstract}
Urban tourism, which has been developing mainly in big cities with a centuries-long history, is one of the fastest growing form of tourism. Global transformation in the international tourist market moves cities towards the introduction of efficient restructuring that is necessary for adaptation to new trends in tourism as well as to offer different forms of recreation for tourists.

The aim of the paper is to show the role of entrepreneurship of the local government and inhabitants for the development of various forms of urban tourism in Valencia, located on the Spanish coast of the Mediterranean Sea. Furthermore, the paper presents a number of institutional arrangements designed to increase tourism and improve the competitiveness of the city.
\end{abstract}

Słowa kluczowe: Hiszpania; przedsiębiorczość lokalna; turystyka miejska; Walencja

Key words: local entrepreneurship; Spain; urban tourism; Valencia

\section{Wprowadzenie}

Zmiany na międzynarodowym rynku turystycznym, uwarunkowane zarówno czynnikami zewnętrznymi, do których zaliczamy zmieniające się otoczenie społeczne, gospodarcze i polityczne, jak i wewnętrznymi, do których należą elementy infrastruktury turystycznej i usług turystycznych oraz czynniki kształtujące wielkość i strukturę podaży turystycznej, wymuszają na regionach recepcji turystycznej wiele działań innowacyjnych, poprawiających ich konkurencyjność na tym rynku. Współczesne procesy rozwoju społeczno-gospodarczego i kulturowego W różnej skali układów przestrzennych wykazują coraz silniejsze powiązania z procesami roz- 
woju globalnego. Procesy te z jednej zaś przyczyniają się do pobudzania konkurencyjności podmiotów gospodarczych, z drugiej strony powodują podnoszenie atrakcyjności układów przestrzennych dla generowania endogenicznych i przyciągania egzogenicznych czynników rozwoju (Zioło, 2007). Globalne przekształcenia strukturalne wpływają na znaczne zmiany działalności obszarów recepcji turystycznej i prowadzenia wydajnych procesów restrukturyzacyjnych, niezbędnych do dostosowania się do nowych trendów w turystyce. Podstawową rolę w tym zakresie odgrywa lokalna przedsiębiorczość, zarówno władz samorządowych, jak i mieszkańców, w tym głównie przedsiębiorców. Pod pojęciem przedsiębiorczość można rozumieć takie zachowania władz i miejscowej ludności, które zmierzają do poszukiwania nowych zastosowań posiadanych zasobów w celu aktywizacji gospodarczej regionu i zwiększenia jego konkurencyjności (Majewska, 2006). To właśnie przedsiębiorczość jest nowatorstwem polegającym na poszukiwaniu odmienności w porównaniu z tym, co robią inni, znajdowaniu skuteczniejszych sposobów działania na rynku, dających wyższą użyteczność produktów i usług oraz większą efektywność gospodarowania. Jest ona ze swej natury działalnością konkurencyjną w stosunku do postępowania innych przedsiębiorstw. Przedsiębiorczość polega na skłonności do podejmowania nowych, niekiedy ryzykownych i niekonwencjonalnych przedsięwzięć oraz na wykazywaniu inicjatywy w ich poszukiwaniu oraz wdrażaniu w życie (Fabiańska, 1986; Kortan, 1997). Przedsiębiorczość stanowi podstawowy warunek rozwoju gospodarczego, społecznego i kulturowego układów przestrzennych różnej skali (Zioło, 2007, 2011). Problematyka związków pomiędzy przedsiębiorczością a szeroko pojmowanym rozwojem regionalnym, w tym również instytucjonalnym i przestrzennym wymiarem gospodarowania oraz konkurencyjności, jest ważnym i często podejmowanym tematem badań, niejednokrotnie o charakterze interdyscyplinarnym (Krajewski, Śliwa, 2004; Zioło, 2006, 2007, 2011; Zdon-Korzeniowska, 2009, 2011; Kuciński, 2010; Bednarczyk i in., 2010).

Miejscem, które może szybko i skutecznie reagować na zmieniające się wymagania turysty i zapewnić mu usługi o najwyższej jakości pod względem infrastruktury, atrakcji turystycznych oraz zróżnicowanej oferty, jest duże miasto o wielowiekowej tradycji. Jest ono niewątpliwie najważniejszą kategorią przestrzenną turystycznego przeznaczenia świata, a więc uniwersalnym miejscem pełniącym funkcję turystyczną. W strukturach przestrzennych dużych miast ciągle zachodzą przeobrażenia obszarów życia zbiorowego. Pojawiają się w nich nowe, różnorakie inwestycje przeznaczone w dużej mierze dla turystów. Pod ich wpływem miasta przechodzą niekiedy dość istotne przemiany. W badaniach dotyczących turystyki w mieście i organizacji struktur przestrzennych miasta pod wpływem rozwoju turystyki zwraca się uwagę, iż miasta turystyczne prowadzą działalność aktywizującą funkcję turystyczną przez (Judd i in., 2002):

- przemiany struktur przestrzennych w kierunku sprzyjającym napływowi turystów,

- aktywny marketing, promocję miejskich wydarzeń kulturalnych.

Przykładem miasta, które pod wpływem inicjatyw, będących przejawem przedsiębiorczości lokalnej, przystosowało się do zmieniających się warunków rynkowych, dzięki czemu może konkurować na krajowym i międzynarodowym rynku turystycznym, oraz weszło na ścieżkę harmonijnego rozwoju, jest Walencja. Miasto to jest położone na wschodnim wybrzeżu Morza Śródziemnego, przy ujściu rzeki Turii do Zatoki Walenckiej. Jest ono trzecim pod względem potencjału demograficznego i ekonomicznego miastem Hiszpanii, po Madrycie i Barcelonie. W 2013 r. zamieszkiwało je ponad 830 tys. mieszkańców, a cały obszar metropolitalny - ponad 1,5 mln osób, w tym 17\% obcokrajowców. Przez ostatnie 25 lat władze lokalne wypracowały strategiczną pozycję Walencji w ramach procesów hiszpańskiej decentralizacji, przebiegających pod wpływem globalizacji gospodarki i integracji europejskiej. Wykreowanie pozytywnego wizerunku miasta na krajowym i zagranicznym rynku usług turystycznych przekłada się na 
liczbę odwiedzających go turystów. W 2012 r. z miejsc noclegowych skorzystało ponad 1,8 mln turystów, o 2\% więcej niż w roku poprzednim i 125\% więcej niż w $2000 \mathrm{r}$. Liczba udzielonych noclegów w Walencji w 2012 r. przekroczyła 3,9 mln, co dorównuje średniej dla głównych miejskich destynacji europejskich. Z liczby tej ponad 55\% przypadło na turystów zagranicznych i stanowi to prawie dwa razy więcej niż 10 lat temu (Estadísticas de turismo, 2012).

Hiszpański Departament Turystyki wraz z władzami regionalnymi od kilkunastu lat realizuje Plan Turystyki Przybrzeżnej na XXI w., kładący szczególny nacisk na zrównoważony rozwój regionu, innowacyjność i dywersyfikację produktu turystycznego. Celem jest zmiana modelu rozwoju gospodarczego i turystycznego panującego na wybrzeżu Morza Śródziemnego oraz na Wyspach Kanaryjskich i Balearach. Model ten opierał się na turystyce wypoczynkowej oraz na sektorze budownictwa mieszkaniowego i hotelowego, a został zatrzymany z powodu kryzysu gospodarczego.

Plan Turystyki Przybrzeżnej na XXI w. jest kontynuacją inicjatyw podejmowanych od 1990 r., mających na celu rewitalizację i nowoczesną przebudowę dojrzałych ośrodków turystycznych (Lew, 2008). Działania te są zgodne z najbardziej popularną w geografii turyzmu koncepcją cyklu ewolucji obszaru turystycznego, autorstwa R.W. Butlera (1980). Na podstawie tej teorii T. Knowles i S. Curtis (1999) stwierdzili, że hiszpańskie ośrodki turystyczne opierające swą działalność na słońcu, piasku i morzu, które rozwijały się szybko od 1960 r., czeka nieodwracalny spadek zainteresowania z powodu zmiany motywacji konsumentów, pojawienia się konkurencyjnych miejsc i spadku popytu w kraju na rzecz podróży zagranicznych. W przeciwieństwie do nich E. Aguiló, J. Alegre i M. Sard (2005), na podstawie wzrostu liczby przyjazdów turystycznych i poziomu zadowolenia klientów na Balearach, wysnuli wniosek o przetrwaniu ośrodków opierających się na modelu słońce - piasek - morze i efektach podjętych w nich inicjatyw. Problematyka roli przedsiębiorczości lokalnej i różnorodnych strategii restrukturyzacyjnych przyjmowana w celu utrzymania konkurencyjności hiszpańskich obszarów nadmorskich jest podejmowana w licznych pracach naukowych (Priestley, Mundet, 1998; Oreja, Parra, Yanes, 2008; Anton, 2011; Garay, Cànoves, 2011; Ivars, Sánchez, Vera Rebollo, 2013).

Walencja to miasto, które przy dużej konkurencji ze strony wielu miast hiszpańskich światowej sławy z roku na rok musi walczyć o potencjalnego turystę. Stąd nasuwa się pytanie: Jakie inicjatywy zostały podjęte przez lokalną społeczność oraz władze miasta i jakie procesy restrukturyzacyjne przeszło miasto, aby stać się konkurencyjnym na rynku turystycznym? Co proponuje miasto, by zachęcić do przyjazdów turystycznych i na jaką kategorię turystów jest ono nastawione? Z postawionych pytań wynika cel niniejszego opracowania, którym jest przedstawienie zasadniczych inicjatyw, zarówno władz miejskich, jak i instytucji prywatnych oraz publicznych, podjętych w celu dywersyfikacji oferty turystycznej i rozwoju różnych form turystyki miejskiej w Walencji oraz rozwiązań instytucjonalnych, zmierzających do zwiększenia ruchu turystycznego i podniesienia konkurencyjności miasta. Przyjmuje się, że działania te są istotnym przejawem przedsiębiorczości lokalnej mieszkańców i władz samorządowych.

\section{Walencja jako produkt turystyczny}

W literaturze przedmiotu obecność turystów w środowisku zurbanizowanym jest traktowana w kontekście funkcji turystycznej miasta jako przejaw turystyki w mieście oraz jako turystyka na obszarach miejskich. Za A. Kowalczykiem (2003) turystykę tę można rozumieć jako wszystkie formy turystyki, które mają miejsce na terenach miejskich, są związane z atrakcyjnością turystyczną miast i których celem jest odwiedzanie i poznanie miasta traktowanego jako dziedzictwo materialne i duchowe, przekazywane z pokolenia na pokolenie i uznawanego za niepodzielny element przestrzeni turystycznej. Miasto stanowi specyficzny rodzaj produktu 
turystycznego. G.J. Ashworth i H. Voogd (1990) stwierdzają, że turystyka miejska oparta jest na produkcie miejsca. Produktem miasta jest jego obszar jako suma obiektów i środków służących rozwojowi turystyki, a atrakcyjność miasta związana jest z jego odmiennością i unikalnością.

Odnosząc powyższe założenia do Walencji i mając na uwadze olbrzymią konkurencyjność pozostałych hiszpańskich miast, nasuwa się pytanie: co proponuje miasto, aby zachęcić turystów do jego odwiedzenia? Jako miejsce wielowiekowej działalności materialnej i duchowej człowieka dla wielu jest ono interesującym obiektem do zwiedzania, zachwycającym pięknem i ogromem budowli sakralnych oraz świeckich. Zabytki Walencji, stanowiące jej dziedzictwo historyczne i artystyczne, skupione są głównie na starówce i w jej okolicach. Należą do nich pałace, place, fontanny, liczne kościoły i katedry. Najstarsza katedra pochodzi z XIII w. i łączy w sobie trzy style architektoniczne: romański, gotycki oraz barokowy. Legenda głosi, że znajdujący się w katedrze skarb, którym jest złoty kielich agatowy, to Święty Graal używany przez Chrystusa w trakcie Ostatniej Wieczerzy. Z tyłu katedry usytuowany jest barokowy kościół Basilica de la Virge dels Desamparats. Dzisiejsza Walencja nazywana jest miastem 100 dzwonnic. Do najsłynniejszych należy gotycka wieża Miguelete (1381-1424) przylegająca do katedry oraz sześcioboczna wieża Santa Katalina (1688-1705) stanowiąca doskonały przykład walenckiego baroku. Do najciekawszych świeckich budowli zaliczana jest La Lonja, czyli Giełda Jedwabiu, która jest wpisana na Listę światowego dziedzictwa kulturalnego i przyrodniczego UNESCO. La Lonja została zbudowana w stylu gotyckim i uznaje się ją za jedną z najpiękniejszych budowli świeckich w całej Europie. Interesującymi obiektami są również modernistyczna hala targowa z początku XX w. i wnętrze dworca kolejowego zdobione ceramiką. Produkty turystyczne związane $\mathrm{z}$ dziedzictwem historycznym mają duże znaczenie w rozwoju turystyki miejskiej i kulturowej Walencji, jednak to nie one są głównym magnesem przyciągającym potencjalnych turystów.

W 1982 r. Walencja z rolniczego i ciągle prowincjonalnego miasta została przekształcona w stolicę nowego autonomicznego regionu Comunidad Valenciana, obejmującego trzy prowincje leżące wzdłuż wschodnich wybrzeży Morza Śródziemnego: Castellón, Walencję i Alicante. Stała się ona śródziemnomorskim centrum kulturalno-gospodarczym oraz ważną destynacją turystyczną. Początkiem „nowego miasta z pomysłem na nadchodzące jutro” stał się zbudowany w 1987 r. Pałac Muzyki. Z inicjatywy władz miejskich powstał projekt na zagospodarowanie terenów znajdujących się wokół samego centrum miasta. Zadecydowano, że będzie to Ciudad de las Artes y las Ciencias - Miasto Sztuki i Nauki, stanowiące najbardziej futurystyczny ośrodek Walencji. Obecnie jest to ogromny, nowoczesny kompleks kulturalno-rozrywkowy, który zaprojektował słynny walencki architekt Santiago Calatrava. Obiekt znajduje się w dawnym korycie rzeki Turia, od strony morza, a każdego roku miliony turystów odwiedzają go dla samej awangardowej architektury. Miasto Sztuki i Nauki to tzw. nowe miasto, miasto przyszłości, które zasługuje na prawdziwe uznanie i stało się ikoną Walencji. Łączna powierzchnia całego kompleksu wynosi 350 tys. $\mathrm{m}^{2}$. Całość składa się z sześciu części architektonicznych: Museo de las Ciencias Príncipe Felipe (innowacyjne centrum interaktywnej nauki XXI w.), Oceanográfic (największe akwarium w Europie z ponad 500 gatunkami fauny morskiej), Hemisféric (kino IMAX i projekcji cyfrowych), Umbracle (pawilony wystawowe i parkingi), Palau de les Arts Reina Sofía i Agora (gmach teatralno-operowy, obiekty kongresowe). Mieszczą się tu również ogrody z roślinnością śródziemnomorską oraz liczne kawiarnie i restauracje.

Niezbędnym elementem każdej przestrzeni miejskiej, która ma funkcje turystyczne, jest jej infrastruktura turystyczna. Powinna się ona cechować bardzo wysokim stopniem dywersyfikacji jakościowej, a w konsekwencji - cenowej. Przejawem przedsiębiorczości lokalnej, zarówno instytucji publicznych, jak i prywatnych, były więc w Walencji działania proinwestycyjne 
w bazę noclegową, jak również położenie nacisku na poprawę jakości już istniejących miejsc noclegowych i usług turystycznych, zgodnie z zaleceniami Hiszpańskiego Instytutu Jakości Turystycznej (ICTE). W 2012 r. Walencja miała 69 skategoryzowanych hoteli - w porównaniu z 2000 r. liczba ta była większa o 77,5\%, w tym o prawie 300\% zwiększyła się liczba hoteli czterogwiazdkowych, dysponujących 51\% wszystkich pokoi. Ogólna liczba miejsc noclegowych w mieście w skategoryzowanych hotelach wynosiła 15 680, co stanowiło prawie 50\% miejsc noclegowych w całej prowincji (33 731). Do luksusowych obiektów noclegowych należą apartamenty. Od 2000 r. ich liczba w mieście wzrosła ponad czternastokrotnie, jest to 816 apartamentów dysponujących ponad 2,7 tys. miejsc noclegowych. Ponadto, w mieście znajduje się 20 hosteli, 39 pensjonatów i 2 campingi. Na terenie miasta można skorzystać z 2352 restauracji i barów różnej kategorii (Estadísticas de turismo, 2012).

Spośród walorów przyrodniczych dominujące znaczenie mają nadmorskie położenie Walencji, występowanie piaszczystych plaż i słonecznego klimatu. W granicach miasta jest $20 \mathrm{~km}$ dostępnej piaszczystej plaży, a jej średnia szerokość to ok. $60 \mathrm{~m}$. Znajdujące się zaledwie 15 min drogi od historycznego centrum miasta plaże Las Arenas, Malvarrosa i El Cabañal mają certyfikat Błękitnej Flagi. Ponadto, najdziksze plaże Walencji leżą w odległości zaledwie $10 \mathrm{~km}$ od centrum. Są one zachowane w stanie naturalnym, w otoczeniu wydm i gęstej roślinności Parku Przyrody Albufera.

Zrównoważony rozwój jest ważnym kryterium oceny ośrodków turystycznych, jak również elementem zapewnienia ich konkurencyjności. Przeludnienie miejsc przybrzeżnych z powodu rozwoju turystyki zawsze miało katastrofalny wpływ na środowisko lokalne. Przedsiębiorczość władz miasta i regionu oraz lokalnej społeczności doprowadziła do ochrony obszarów cennych ekologicznie, powstania parków i ogrodów przystosowanych do celów rekreacyjno-sportowych. Podejście skoncentrowane na ochronie środowiska przyrodniczego zapewniło stworzenie produktu turystycznego związanego z naturą oraz poszerzenie wachlarza możliwości rekreacyjnych, nieidentyfikowanych tylko z plażami. Na sieć obszarów chronionych aglomeracji walenckiej składają się dwa parki przyrody. Jednym z nich jest położony $10 \mathrm{~km}$ na południe od centrum miasta Parc Natural de l'Albufera de València, o powierzchni 21120 ha, z największym jeziorem w Hiszpanii - Albufera - oraz rzadkimi gatunkami ptactwa i roślinności bagiennej. Co roku park ten odwiedza ok. 7,6\% turystów przebywających w Walencji. W 2007 r. utworzono Parc Natural del Turia o powierzchni 4692 ha, obejmujący dno doliny Turia na północny zachód od miasta. Walencja, oferując ponad 4,8 $\mathrm{km}^{2}$ terenów zielonych, przystosowanych do celów rekreacyjnych, biernego i czynnego wypoczynku jest uznawana za autentyczne zielone miasto. Tereny te to m.in. zabytkowy Jadri Botanic z XVI w., XVIII-wieczne parki Jardins de l'Alameda i Jardins de Monfort oraz powstały w 2008 r. Bioparc Valencia, z florą i fauną afrykańską.

Atutem Walencji jest jej bardzo dobra i zróżnicowana zewnętrzna dostępność komunikacyjna. Miasto jest ważnym węzłem kolejowym, drogowym, lotniczym i morskim. Międzynarodowy port lotniczy Valencia Airport - Manises położony $8 \mathrm{~km}$ na zachód od centrum miasta, przy autostradzie Madryt - Walencja A3, zapewnia miastu dostępność lotniczą. Dzięki niemu ma ono regularne połączenia z niemal wszystkimi głównymi i regionalnymi portami lotniczymi Hiszpanii, ma też ok. 40 połączeń międzynarodowych. W 2012 r. port odnotował 4752020 pasażerów i 59824 tys. operacji lotniczych (http://www.fallasfromvalencia.com). Współczesny turysta do miasta przyjeżdża na krótki czas, wykorzystując w głównej mierze właśnie transport lotniczy (75,4\% turystów zagranicznych), w związku z czym zmuszony jest do korzystania z lokalnego transportu. Linia metra, której stacja połączona jest bezpośrednio z halą odlotów i przylotów, stanowi najszybszy sposób dotarcia do centrum. W mieście funkcjonuje sześć dobrze oznakowanych linii metra. Główną stacją kolejową w Walencji jest stacja północna - 
Estación del Norte, znajdująca się w samym centrum miasta. Krzyżują się tu linie kolejowe szybkich pociągów pasażerskich z Madrytu i Barcelony, a za jej pośrednictwem - z pozostałą częścią Europy. Walencja dysponuje nowoczesną siecią dróg, dzięki czemu jest łatwo dostępna z dowolnego punktu na półwyspie, a autostrada śródziemnomorska AP-7, która biegnie z północy na południe wzdłuż wybrzeża, połączona jest z europejską siecią autostrad.

Przejawem przedsiębiorczości lokalnej było założenie w 1999 r. specjalnej sieci linii autobusów Valencia Bus Turistic nastawionej na potrzeby turystyki. Linia czerwona Valencia Historica obwozi turystów po zachodniej, zabytkowej części miasta. Linia niebieska - Valencia Maritima - dowozi turystów do portu morskiego, natomiast linią zieloną Albufera Bus Turistic, turyści mogą dostać się nad jezioro Albufera. Sieć Bus Turistic ma stworzony indywidualny system audio, który pozwala operować kilkoma językami jednocześnie.

W Walencji znajduje się jeden z największych portów morskich w Hiszpanii - El Grao de Valencia. Jest on zintegrowany z portami sąsiadującymi, znajdującymi się w Gandii oraz Sagunto. Jako jeden port o łącznej długości ponad $80 \mathrm{~km}$ zaliczany jest on do największych portów w basenie Morza Śródziemnego. Łączna przepustowość ładunków w ciągu roku dochodzi do ok. $55 \mathrm{mln}$ ton. W porcie zatrudnionych jest blisko 15 tys. pracowników, którzy oferują swoje usługi dla ponad 7 tys. statków w ciągu roku. Obsługiwane są w nim statki handlowe, rybackie, promy pasażerskie oraz jachty. Codziennie wypływają z niego statki, którymi można dostać się na Majorkę, Minorkę oraz Ibizę. W 2011 r. port obsłużył 378463 pasażerów (http://www.vanudenmaritime. com/).

\section{Modernizacja i rewitalizacja Walencji oraz ich wplyw na dywersyfikację oferty turystycznej} Konkurencyjność turystyczna regionu Walencji ma kluczowe znaczenie w działaniach przedsiębiorczych władz samorządowych i programach planowania na szczeblu lokalnym oraz regionalnym. W pierwszym etapie planu rewitalizacji Walencji inicjatywy publiczne koncentrowały się na urbanistyce i poprawie stanu środowiska miasta w celu ,podniesienia konkurencyjności ze słońcem i piaszczystymi plażami”. Celem samorządu lokalnego w starannie zaplanowanej polityce rozwoju miasta było przekształcenie Walencji z ośrodka wypoczynku w główny ośrodek turystyki kulturalno-rozrywkowej regionu. Plany te dotyczyły przede wszystkim terenów położonych na południowy wschód od centrum miasta, wzdłuż dawnego koryta rzeki Turia, gdzie w latach 1991-2005 powstało omawiane wcześniej nowoczesne Miasto Sztuki i Nauki z awangardową architekturą (ryc. 1). Ten wielofunkcyjny, unikalny kompleks stworzył znaczącą przewagę konkurencyjną w stosunku do innych miast. Aktywność władz i przedsiębiorców przyczyniła się do powstania na południowym brzegu dawnego koryta rzeki całkiem nowej dzielnicy w nowoczesnym stylu śródziemnomorskim, z wieżowcami mieszkalnymi, hotelami, restauracjami i centrami handlowymi, połączonej zielonymi bulwarami z centrum miasta i portem (Prytherch, 2003; Prytherch, Boira Maiques, 2009).

Drugim nadrzędnym celem w polityce miasta było stworzenie z niego międzynarodowego centrum handlu i biznesu, a więc postawienie na turystykę biznesowo-kongresową. Jest ona uznawana za jedną z najbardziej dochodowych form turystyki na świecie, zarówno z punktu widzenia firm świadczących usługi turystyczne i towarzyszące, jak i z punktu widzenia obszarów recepcji turystycznej (Mika, 2007). Pobudza ona rozwój społeczno-ekonomiczny miast, prowadząc do ich modernizacji i rewitalizacji. W Walencji przejawem przedsiębiorczości władz miasta i lokalnej społeczności w zakresie turystyki biznesowo-kongresowej była modernizacja Ferie Valencia - największej w kraju hali targowo-wystawienniczej (230 tys. m²), w której odbywa się rocznie ponad 30 wydarzeń o znaczeniu krajowym oraz międzynarodowym. W jej pobliżu, w północno-zachodniej części miasta, wśród pozostałości gajów cytrusowych, 
Ryc. 1. Zdjęcie lotnicze Walencji z oznaczonymi w kolejności chronologicznej głównymi miejscami podległymi rozbudowie i renowacji

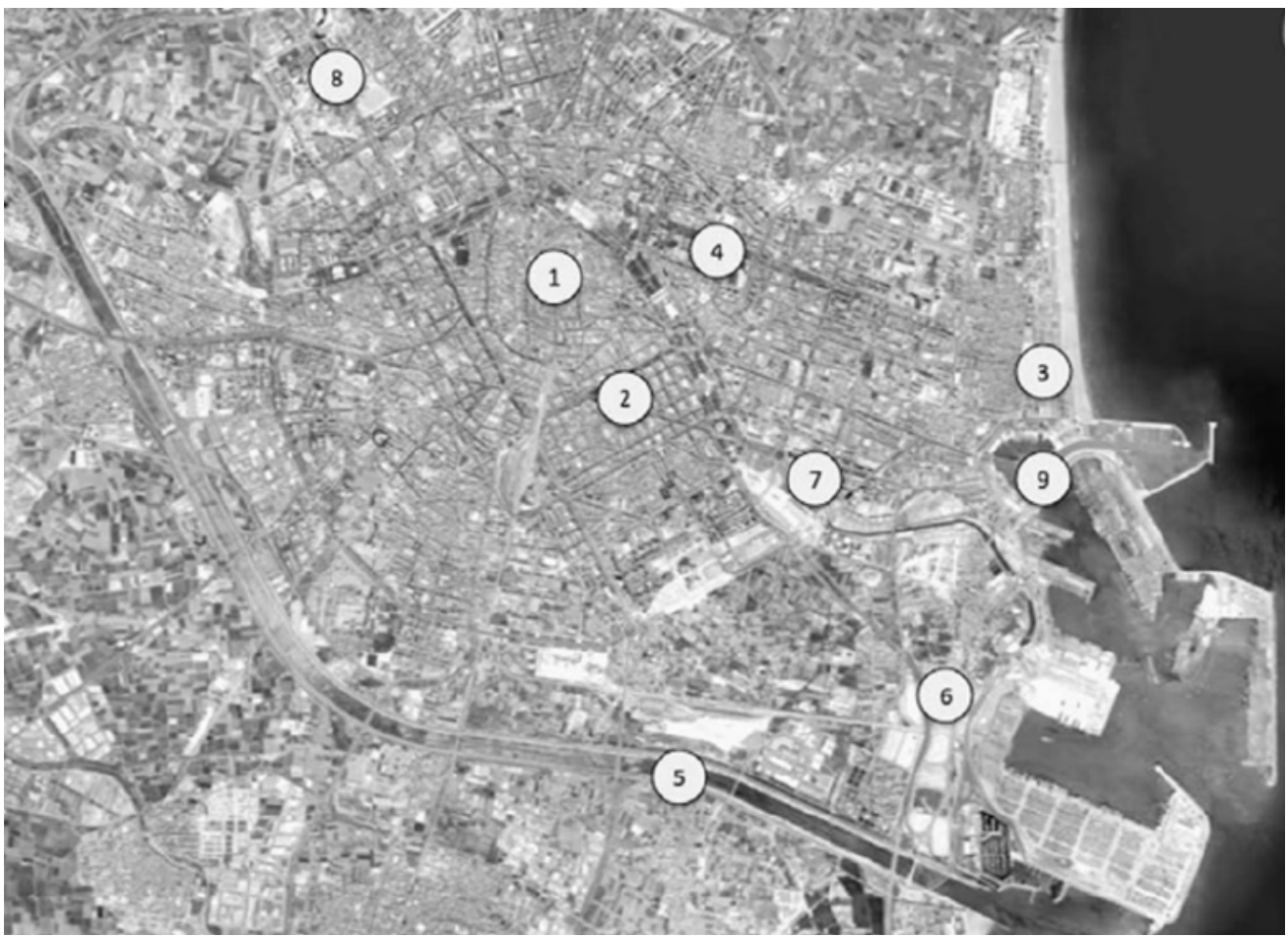

1 - historyczne centrum miasta, 2 - dzielnica Russafa z XIX-wieczną zabudową, 3 - dzielnica przybrzeżna przyłączona do miasta w 1890 r., gdzie w XXI w. powstała jedna z najnowocześniejszych marin na wybrzeżu Morza Śródziemnego: La Marina Real Juan Carlos I, 4 - kampus Uniwersytetu w Walencji, 5 - nowy kanał rzeki Turia zbudowany po powodzi w 1957 r., 6 - rozbudowany port Walencji, 7 - Miasto Sztuki i Nauki wraz z nowoczesną dzielnicą, 8 - Centrum Konferencyjne z Pałacem Kongresowym i zmodernizowaną Feria Valencia oraz położony na południowy zachód Bioparc, 9 - historyczne doki odrestaurowane i przebudowane na 32. Puchar Ameryki w 2007 r. wraz z przyległą dzielnicą rekreacyjno-handlową.

Źródło: Prytherch, Boira Maiques (2009), uzupełnione przez autorkę.

powstały nowoczesne inwestycje, z Pałacem Kongresowym, zaprojektowanym przez znanego architekta Normana Fostera, luksusowymi hotelami, restauracjami i innymi obiektami, stanowiące połączenie z pobliskimi miasteczkami: Benimámet, Burjassot i Paterna (Prytherch, Boira Maiques, 2009). Inwestycje te, wraz z Miastem Sztuki i Nauki, oraz gościnność i wysoki poziom usług uczyniły z Walencji idealne miejsce na odbywające się przez cały rok krajowe i międzynarodowe wystawy, kongresy i spotkania biznesowe. W 2012 r. uczestniczyło w nich ponad 181,5 tys. osób (Estadísticas de turismo, 2012).

Kolejnym przejawem postaw i działań przedsiębiorczych władz oraz mieszkańców były inwestycje w porcie i dzielnicy portowej, które przyczyniły się do rozwoju miasta jako europejskiego ośrodka handlu morskiego, portu pasażerskiego oraz centrum rekreacyjno-sportowego. Doki Walencji wraz z zabytkowymi magazynami zostały odrestaurowane i przekształcone w nowoczesne zabudowania i centrum rekreacyjno-handlowe w ramach przygotowań do jednych z najbardziej prestiżowych regat świata - 32. Pucharu Ameryki w Wyścigu Żeglarskim, który odbył się w 2007 r. (Boira Maiques, 2007). Inwestycje te stworzyły nową kosmopolityczną 
przestrzeń publiczną odwiedzaną głównie przez turystów, ale też przez mieszkańców miasta, stanowiącą jedną z najważniejszych atrakcji regionu. La Marina Real Juan Carlos I jest nazwą nadaną nowej przystani żeglarskiej w Walencji, na północ od portu handlowego, wzdłuż plaży Malvarrosa, która jest najnowocześniejszą mariną w basenie Morza Śródziemnego i dzielnicą rozrywki z wieloma pubami i restauracjami.

Do szczególnych cech współczesnej turystyki należy zaliczyć przejście od turystyki typu pasywnego do przeżyć, wrażeń, klimatu społecznego i psychicznego związanego z miejscem pobytu, osłabienie zależności od dziedzictwa przyrodniczego i kulturowego. Do tego trendu nawiązały wysiłki władz lokalnych na rzecz organizacji imprez sportowych. Port w Walencji jest miejscem wyścigów Formuły 1 Grand Prix Europy, na potrzeby których oddawane są dwie z głównych ulic miasta. Tor wyścigowy znajdujący się w miejscowości Cheste, oddalonej od Walencji o $20 \mathrm{~km}$, jest miejscem wyścigów motocyklowych, jak również treningów Formuły 1, ściągających setki turystów. W 2011 r. Walencja została doceniona jako miasto rozwoju sportu i otrzymała tytuł Europejskiej Stolicy Sportu.

Zauważono, że coraz częściej wartością turystyczną staje się uczestnictwo w autentycznych, tradycyjnych wydarzeniach regionalnych, ich wspólne przeżywanie i doświadczanie, a głównym produktem turystycznym jest uczucie przyjemnego, ekscytującego spędzenia czasu i wspomnienia, które nierzadko doprowadzają do powrotu do miejsca, w którym czas był spędzony miło i przyjemnie. Stąd też dodatkowe wysiłki władz lokalnych i mieszkańców Walencji wiążą się z organizowaniem i rozpowszechnianiem imprez kulturalnych, zwłaszcza poza sezonem turystycznym, oraz wykorzystaniem folkloru i tradycyjnej kultury ludowej dla potrzeb turystyki. W rozwoju regionalnym ważne stało się nie tylko pielęgnowanie tradycji i poczucia tożsamości z zamieszkiwanym obszarem, ale także poszukiwanie rozwiązań zmierzających do wykorzystania dziedzictwa materialno-kulturowego dla korzyści ekonomicznych i podnoszenia jakości życia mieszkańców. Z 3200 ważniejszych fiest odbywających się w całej Hiszpanii (Sanchez, 1999) w Walencji odbywa się w ciągu roku kilkaset, co czyni to miasto nie tylko regionalnym ośrodkiem kulturalno-rozrywkowym, ale też ośrodkiem przyciągającym turystów z zagranicy. Imprezy organizowane w Walencji obfitują w bogactwo muzyki, kolorystyki, jedwabnych regionalnych strojów, a przede wszystkim ognia pod każdą postacią, zwłaszcza ukazanego w fajerwerkach, które dominują podczas każdej fiesty. Mieszkańcy Walencji w ten sposób upamiętniają stare tradycje i wydarzenia historyczne. Szczególne atrakcje zapewnia Las Fallas - święto ognia i fajerwerków, które przypada na połowę marca, kiedy to Walencja przemienia się w gigantyczne ognisko. Na placach miasta płoną karykatury postaci z pierwszych stron gazet, lokalnych polityków, gwiazd kina, a na walki z bykami przybywają najlepsi torreadorzy. Impreza ta przyciąga rokrocznie ponad 1,2 mln odwiedzających (Sanchez, 1999). Fajerwerki królują również w obchodzony 9 października Dzień Wspólnoty Walenckiej, poprzedzony Międzynarodowym Festiwalem Fajerwerków. Hucznie i kolorowo odbywają się także liczne święta kościelne (Kunicki, Ławecki, 2008). W pobliskiej miejscowości Buñol co roku w sierpniu odbywa się La Tomatina, czyli bitwa na pomidory, ściągająca również ogromną liczbę turystów.

Stolica prowincji znana jest dobrze z niezwykłego życia nocnego. El Carmen to jedna z najatrakcyjniejszych dzielnic miasta, stanowiąca centrum rozrywkowe Walencji, słynąca z bardzo intensywnego życia nocnego. Ciasne uliczki i stare, zabytkowe budowle stają się tłem dla odbywających się w licznych pubach imprez, hucznych zabaw i dyskotek.

Istotnym przejawem przedsiębiorczości lokalnej Walencji są działania w zakresie marketingu terytorialnego, które mają na celu promowanie jej jako miasta mogącego zaspokoić potrzeby niezwykle wymagających, zamożnych turystów, oczekujących niezwykłej satysfakcji 
w zakresie wyłączności, wyróżnienia, jakości, wyjątkowości i indywidualnego podejścia. Ten rodzaj turystyki obejmuje kilka usług high-end lub takich, jak np. golf, luksusowe hotele, renomowane restauracje, unikalne imprezy kulturalne lub sporty wodne. Wszystkie te elementy oferuje miasto, w którym znajduje się pięć hoteli pięciogwiazdkowych i jeden w obszarze metropolitalnym, pięć restauracji nagrodzonych gwiazdką Michelin, a także Palau de la Música i Palau de les Arts, które zapraszają najlepszych artystów muzyki klasycznej, opery i baletu. Ponadto Walencję wyróżnia La Marina Real Juan Carlos I - jedna z najnowocześniejszych marin na wybrzeżu Morza Śródziemnego, która oferuje wszystkie usługi dla jachtów, a w pobliżu miasta rozlokowanych jest 10 pól golfowych.

Renowacja miasta, jego przebudowa i nowoczesna rozbudowa oraz dywersyfikacja oferowanych usług, będąca przejawem aktywności i przedsiębiorczości władz i lokalnego biznesu, przyczyniły się do odkrycia Walencji przez krajowych i zagranicznych turystów oraz imigrantów. W 1992 r. Walencję odwiedziło niecałe 400 tys. turystów, podczas gdy w 2007 r., przed światowym kryzysem gospodarczym, liczba odwiedzających osiągnęła prawie 2 mln i 25\% wzrost w stosunku do 2006 r., z czego 40\% stanowili obcokrajowcy. Wśród odwiedzających $58 \%$ przybyło w celach wypoczynkowych, a pozostali - w celach biznesowych. W $2012 \mathrm{r}$. liczba przyjezdnych w celach wypoczynkowych wzrosła do 64\% (Estadísticas de turismo Valencia, 2012). To „,prowincjonalne miasto” i ,stolica anty-turystyki”, jak określił Walencję jeden z brytyjskich krytyków Kenneth Tynan, w 1996 r. miało 9 muzeów, które odwiedziło zaledwie 0,5 mln osób, a już w 2007 r. liczyło 30 muzeów z 6,6 mln odwiedzającymi (Prytherch, Boira Maiques, 2009). Obecnie w Walencji mieści się 47 muzeów, w których można podziwiać obiekty z zakresu sztuki, historii, kultury i architektury, oraz 13 teatrów (http:/www.visitvalencia.com/).

Okres do 2007 r. charakteryzował się boomem na hiszpańskim rynku nieruchomości, co doprowadziło do rozwoju turystyki rezydencjalnej. Badania R.S. Gonzáleza (2008) potwierdziły, że hiszpańskie destynacje turystyczne na wybrzeżu Morza Śródziemnego przyciągają klientów nieruchomości nowoczesnymi inwestycjami, infrastrukturą, ceną i wysokim poziomem usług. Nowe wymagania jakościowe wymusiły na rynku inwestycji remont istniejącej bazy hotelowej i zastosowanie nowych technologii. Działania te konsekwentnie miały tendencję wzrostową i były kluczowym czynnikiem utrzymania konkurencyjności i przetrwania na rynku.

Kolejnym przejawem aktywności i przedsiębiorczości lokalnej było wczesne zwrócenie uwagi w ofercie usług turystycznych na niszową na tym rynku, lecz ciągle wzrastającą grupę osób niepełnosprawnych i seniorów. W gospodarce turystycznej opartej na wiedzy osoby niepełnosprawne stają się współtwórcami wartości oferowanej na rynku. Społeczeństwa Unii Europejskiej zainicjowały szereg programów wspierających równouprawnienie i wyrównywanie szans pełnego doznawania przyjemności podróżowania przez osoby z niepełnosprawnością. Idee te spotkały się z dużym poparciem państw europejskich i do dziś są kontynuowane (Grabowski, 2008). W Hiszpanii żyją 4 mln osób z niepełnosprawnością, a grupa ludzi w wieku powyżej 65 roku życia ciągle wzrasta. Ponadto, tę grupę konsumentów można uznać za multi-client. Szacuje się, że jedna osoba niepełnosprawna na dwie osoby niepełnosprawne podróżuje z osobą towarzyszącą. Wykorzystanie tego segmentu rynku znacznie wpływa na obniżenie zjawiska sezonowości.

Szczególną uwagę zwrócono na grupę turystów niepełnosprawnych, poprawiając jakość miejsc noclegowych, dostęp do plaż, sprzętu i usług turystycznych. Osoby niepełnosprawne mogą znaleźć bardzo atrakcyjne opcje w programach oferowanych przez firmy przewodnickie, w organizowanych imprezach sportowo-rekreacyjnych, kulturalnych czy kulinarnych. W samej 
Walencji w ciągu ostatnich czterech lat nastąpił 50\% wzrost liczby turystów powyżej 65 . roku życia (Turismo Valencia, 2012). W ofercie turystycznej miasta występuje również szeroki zakres usług związanych z urodą i zdrowiem. Walencja ma ok. 30 sklepów, które oferuja produkty i zabiegi dla zdrowia, dobrego samopoczucia i urody, skierowane do konkretnych profili turystów.

\section{Podsumowanie}

Klimat, jakość plaż, standard usług i bazy noclegowej oraz doskonały stosunek jakości do ceny i zetknięcia tradycji z nowoczesnością zapewniają Walencji konkurencyjność i przetrwanie na zmieniającym się rynku turystycznym. Cechy te są wzmocnione przez lokalne inicjatywy prywatnych i publicznych firm, dążących do dywersyfikacji oferowanych produktów turystycznych. W wyniku rewitalizacji i rozbudowy powstało miasto kontrastów, zestawienia tradycji regionalnej i dziedzictwa z globalną nowoczesnością, gdzie ogromne imprezy i festiwale oraz awangardowa architektura sąsiadują z monumentalnymi zabytkami i rozsianymi wokół polami uprawnymi, stanowiącymi przykład krajobrazu kulturowego, ze starożytnym systemem pól uprawnych, sadów i rowów nawadniających.

Walencja jest jedną z najdynamiczniej rozwijających się europejskich destynacji turystycznych w ostatnich latach. Położona nad morzem, w jednym z najcieplejszych rejonów Europy, stała się miejscem często wybieranym zarówno przez turystów krajowych, jak i zagranicznych. Większym powodzeniem cieszyła się wcześniej wśród turystów pochodzących z Hiszpanii, którzy wybierają rejon Walencji na okres świąteczny, weekendowy lub wakacyjny. Dane statystyczne dowodzą jednak, że od 2011 r. turyści zagraniczni stanowią już ponad 55\% ogółu turystów odwiedzających miasto. Przedsiębiorczość i aktywność władz oraz mieszkańców sprawiły, że Walencja jest miastem intensywnie zmieniającym swoje oblicze. Liczne inwestycje i prowadzona działalność marketingowa doprowadziły do tego, że ma ona atrakcyjną ofertę odpowiednią dla wszystkich grup odbiorców. Miasto ma wspaniałe zabytkowe budowle, muzea, ogrody oraz najbardziej nowoczesne, futurystyczne obiekty turystyczne, przyciągające rokrocznie olbrzymią liczbę turystów. Jest ciągle znaczącym ośrodkiem w turystyce wypoczynkowej i rodzinnej, ale coraz większe znaczenie odgrywa w nim turystyka biznesowa i motywacyjna. Międzynarodowy rynek spotkań w Hiszpanii jest podzielony między Barceloną, Madrytem a Walencją, która szczyci się trzecim miejscem w Europie, według statystyk ICCA (International Congress and Convention Association), jako miasto międzynarodowych kongresów, seminariów i wystaw niebędące stolicą kraju. W 2010 r. Palacio de Congresos de Valencia został wybrany przez AIPC najlepszym centrum kongresowym świata, a odwiedza go rocznie ok. 1,3 mln osób (http://www.turisvalencia.es).

Sektor turystyki odgrywa bardzo ważną rolę w gospodarce miasta, generując znaczne dochody bezpośrednie i pośrednie. Walencja szacuje, że wpływy z turystyki w 2012 r. osiągnęły ponad 1,5 mld euro. Turystyka jest kluczowa w strategiach rozwoju miasta i regionu, zarówno dla władz lokalnych i regionalnych, jak i prywatnych przedsiębiorców. Czołową organizacją, której celem jest zarządzanie strategiczne i promocja Walencji w sektorze turystycznym, z najbardziej profesjonalnym podejściem, łączącym interesy publiczne i prywatne, jest Fundación Turismo Valencia. Jest to prywatna organizacja non-profit, w skład której wchodzą przedstawiciele Rady Miasta, Izby Handlowej, Konfederacji Biznesu Walencji oraz lokalnego przemysłu turystycznego. Działalność Fundacji jest finansowana z udziału wszystkich partnerów i instytucji założycielskich oraz własnych dochodów. Od powstania Fundacji w $1991 \mathrm{r}$. liczba firm związanych z turystyką w Walencji wzrosła z 90 w 2000 r. do 240 w 2010 r., co jest dobrym barometrem rozwoju branży turystycznej miasta. Aktywna, przedsiębiorcza działalność 
Fundacji przyczyniła się do ewolucji Walencji, rozwoju infrastruktury turystycznej i usług komplementarnych, przeprowadzenia profesjonalnych szkoleń, wprowadzenia nowoczesnych technologii i dywersyfikacji produktu turystycznego. Prowadzi ona i promuje badania oraz analizy w zakresie turystyki miejskiej, opracowuje broszury, foldery, materiały i akcje promocyjne oraz profesjonalną, innowacyjną komunikację internetową.

Działania i postawy przedsiębiorcze, zarówno władz lokalnych i regionalnych, jak i mieszkańców, przyczyniły się do wzrostu konkurencyjności Walencji na zmieniającym się rynku turystycznym, czego wyrazem jest wzrost liczby turystów i generowanych dochodów. Długoterminowe strategie rozwoju turystyki w mieście i regionie opierają się na następujących priorytetach: wysokiej jakości zróżnicowanych produktów i usług oraz adekwatnej, konkurencyjnej dla nich ceny, zrównoważonego rozwoju, zwiększenia rentowności turystyki w mieście oraz silnej kampanii promocyjnej i marketingowej, z nowoczesnymi formami komunikacji, promocji i informacji skierowanej do różnych grup odbiorców. Przy szybko zmieniających się trendach w turystyce oraz postępujących procesach globalizacji tylko najlepsze i potrafiące się wypromować miejsca mogą zyskać renomę i coraz bardziej wymagającego turystę.

\section{Literatura \\ References}

Aguiló, E., Alegre, J., Sard, M. (2005). The persistence of the sun and sand tourism model. Tourism Management, 26, 219-231.

Anton, S. (2011). Dinámicas de reestructuración de los destinos turísticos litorales del Mediterráneo. Perspectivas y condicionantes. W: D. López (ed.), Renovación de destinos turísticos consolidados. Valencia: Tirant Lo Blanch, 23-40.

Ashworth, G.J., Voogd, H. (1990). Selling the City: Marketing Approaches in Public Sector Urban Planning. London: Belhaven.

Bednarczyk, M. (red.) (2010). Przedsiębiorczość w turystyce. Zasady i praktyka. Warszawa: Wyd. CeDeWu.

Boira Maiques, J.V. (2007). La dársena histórica del puerto: transformaciones and El puerto en elsiglo XX y XXI. En Historia del Puerto de Valencia. Universitat de València.

Butler, R.W. (1980). The concept of a tourist area cycle of evolution: implications for management of resources. The Canadian Geographer, 24, 1, 5-12.

Estadísticas de turismo, 2012, (2014, 18 styczeń). Pozyskano z: http://www.turisvalencia-guias.info/ turisvalencia/estadisticas/\#/1/zoomed.

Fabiańska, K. (1986). Planowanie rozwoju przedsiębiorstwa. Warszawa: PWE.

Garay, L., Cànoves, G. (2011). Life cycles, stages and tourism history: the Catalonia (Spain) experience. Annals of Tourism Research, 38, 2, 651-671.

González, R.F. (2008). El papel de los destinos turísticos en la transformación sociodemográfica del litoral mediterráneo español. Boletín de la Asociación de Geógrafos Españoles, 47, 79-107.

Grabowski, J. (2008). Projekty na rzecz rozwoju turystyki osób niepełnosprawnych. W: A. Stasiak (red.) Rola krajoznawstwa i turystyki w życiu osób niepetnosprawnych. Warszawa: Wydawnictwo PTTK „Kraj”.

Ivars J.A., Sánchez I.R., Vera Rebollo J.F. (2013). The evolution of mass tourism destinations: New approaches beyond deterministic models in Benidorm (Spain). Tourism Management, 34, 184-195.

Judd, R.D., Winter, W., Barnes, W.R., Stern, E. (2002). Tourism and Entertainment as Local Economic Development: A National Servey. D.R. Judd (red.) The Infrastructure of Play: Building the Tourist City. New York, M.E. Sharpe, 50-76. 
Knowles, T., Curtis, S. (1999). The market viability of European mass tourist destinations. A post-stagnation life cycle analysis. International Journal of Tourism Research, 1, 87-96.

Kortan, J. (red.) (1997). Podstawy ekonomiki i zarządzania przedsiębiorstwem. Warszawa: Wydawnictwo C.H. Beck.

Kowalczyk, A. (2003). Geografia turyzmu. Warszawa: PWN.

Krajewski, K., Śliwa, J. (2004). Lokalna przedsiębiorczość w Polsce. Uwarunkowania rozwoju. Warszawa: Wydawnictwo Naukowe Wydziału Zarządzania UW.

Kuciński, K. (red.) (2010). Przedsiębiorczość a rozwój regionalny w Polsce. Warszawa: Wydawnictwo Difin.

Kunicki, K., Ławecki, T. (2008). Hiszpania - cuda świata. Warszawa: Wydawnictwo NMC.

Lew, A. (2008). Long tail tourism: new geographies for marketing niche tourism products. Journal of Travel \& Tourism Marketing, 25, 3-4, 409-419.

Majewska, J. (2006). Wyzwalanie ducha przedsiębiorczości w środowisku społecznym gminy dla rozwoju lokalnego. Przedsiębiorczość - Edukacja, 2, 91-100.

Mika, M. (2007). Rodzaje i formy turystyki. W: W. Kurek (red.), Turystyka. Warszawa: PWN.

Oreja, J.R., Parra, E., Yanes, V. (2008). The sustainability of island destinations: tourism area life cycle and teleological perspectives. The case of Tenerife. Tourism Management, 29, 53-65.

Priestley, G., Mundet, L. (1998). The post-stagnation phase of the resort cycle. Annals of Tourism Research, 25(1), 85-111.

Prytherch, D.L. (2003). Urban planning and a Europe transformed: The landscape politics of scale in Valencia. Cities, 20(6), 421-428.

Prytherch, D.L., Boira Maiques, J.V. (2009). City profile: Valencia. Cities, 26, 103-115.

Sanchez, M. (1999). Fiestas Populares, Espana Dia a Dia, Madrid: Maeva Ediciones.

Zdon-Korzeniowska, M. (2009). Jak ksztaltować regionalne produkty turystyczne? Teoria i praktyka. Kraków: Wydawnictwo Uniwersytetu Jagiellońskiego.

Zdon-Korzeniowska, M. (2011). Marketing terytorialny jako forma działań przedsiębiorczych samorządów terytorialnych w Polsce. Przedsiębiorczość - Edukacja, 7, 188-196.

Zioło, Z. (2006). Rola przedsiębiorczości w podnoszeniu konkurencyjności społeczeństwa i gospodarki. Przedsiębiorczość - Edukacja, 2, 10-17.

Zioło, Z. (2007). Rola przedsiębiorczości w aktywizacji gospodarczej - zarys modelu. Przedsiębiorczość - Edukacja, 3, 10-17.

Zioło, Z. (2011). Rola przedsiębiorczości w warunkach nasilających się procesów globalizacji. Przedsiębiorczość - Edukacja, 7, 10-23.

\section{Źródla internetowe}

http://www.turisvalencia.es

http://www.turisvalencia-guias.info/turisvalencia/estadisticas/\#/1/zoomed

http://www.vanudenmaritime. com//sheet/Valencia/

http://www.visitvalencia.com/

Małgorzata Bajgier-Kowalska, doktor/adiunkt, Krakowska Akademia im. Andrzeja Frycza Modrzewskiego, Wydział Prawa, Administracji i Stosunków Międzynarodowych, Katedra Turystyki Międzynarodowej i Geografii Społecznej.

Zainteresowania naukowo-badawcze i tematyka publikacji koncentrują się wokół problemów geomorfologicznych oraz zagadnień z zakresu geografii regionalnej. Badania autorki dotyczą również problematyki rozwoju turystyki i rekreacji, głównie uwarunkowań rozwoju i funkcjonowania regionów turystycznych na świecie, analizy przestrzennego zróżnicowania zagospodarowania turystycznego oraz wielkości ruchu turystycznego. 
Malgorzata Bajgier-Kowalska, PhD, Adiunkt (an assistant professor), Andrzej Frycz Modrzewski Kracow University, Department of International Tourism and Social Geography, Faculty of Law, Administration and International Relations. The author's scientific and research interests as well as the publication topics are concentrated around the geomorphology problems and the issues relating to regional geography. The author's research is also focused on the problem of tourism and recreation growth, particularly on the question with respect to development conditions and functioning of tourist regions in the world, including the analyses of spatial differentiation of tourist infrastructure and the size of tourism itself.

Adres/Address:

Krakowska Akademia im. Andrzeja Frycza Modrzewskiego

Wydział Prawa, Administracji i Stosunków Międzynarodowych Katedra Turystyki Międzynarodowej i Geografii Społecznej

ul. Gustawa Herlinga-Grudzińskiego 1

30-705 Kraków, Polska

e-mail: malbajkow@interia.pl 